\title{
Parental alienation diagnosis. A modern and effective subtype of domestic violence, endemic in Italian courts
}

\author{
Maria Serenella Pignotti
}

From 70th Congress of the Italian Society of Pediatrics, Joint National Meeting SIP, SICUPP, SITIP

Palermo, Italy. 11-14 June 2014

In 1985 Gardner, publishing on sexual abuse [1], described a clinical picture, Parental Alienation Syndrome (PAS) as a "disorder that arises primarily in the context of childcustody disputes. Its primary manifestation is the child's campaign of denigration against a good, loving parent, a campaign that has no justification."[2]. Originally Gardner defined PAS in gender specific terms, mothers as alienators and fathers as victims. Later, he claimed that either parent could be an alienator [2]. However, almost always, PAS affects women. Gardner specified "when true parental abuse and/or neglect is present the child's animosity may be justified, and so the parental alienation syndrome diagnosis is not applicable" [2] but never clarified how to make such differential diagnosis [3-5]. In Gardner's mind, women involved in divorce trial become psychopathic in the sphere of life related to parenting [6], although PAS "is not only simply a matter of brainwashing or programming in that the children contribute their own elements" [4]. It is based on three main principles: a. the children are liars; b. the father's alienation is a mother's responsibility; c. the allegations of maltreatment are false. To a large extent, PAS tautologically presumes lack of justification for the refusal, maternal programming and absence of children's credibility. PAS' treatment, based on legal coercion through court-ordered threats of deprivation of custody to force mothers and children to act with affection toward the father, violates the principles of good medical practices [7]. PAS's theoretical roots lie on Gardner's theory of human sexuality that justifies adult-child sexual contact and gender violence as beneficial to the reproduction of the species and PAS becomes "a defence strategy for abusive fathers, facilitating these men's projection of blame for their children's refusal onto mothers as a counter-claim to, and evidentiary shield against, allegations of violence" in domestic violence cases [7]. PAS is detrimental to children, women and honest men' civil rights and to Justice! It is a tool aimed to punish women and children reacting to a patriarchical system that presumes all reports of male violence are false and punishes protective mothers. According to American Academy of Paediatrics family violence is a paediatric issue[8]. PAS-ideology's influence on family and criminal Court could lead to wrong decisions with foreseeable emotional upset and trauma to the children and consequently to stark outcomes, including murder and suicide, as in the past [6].

\section{Published: 11 August 2014}

\section{References}

1. Gardner RA: Sex Abuse Hysteria: Salem Witch Trials Revisited. NJ: Cresskill, Creative Therapeutics; 1991.

2. Gardner RA: Denial of the Parental Alienation Syndrome Also Harms Women. Am J Fam Ther 2002, 30:191-202.

3. Gardner RA: True and false accusations of child sex abuse. NJ: Cresskill, Creative Therapeutics; 1992.

4. Gardner RA: Differentiating between parental alienation syndrome and bona fide abuse-neglect. Am J Fam Ther 1999, 27:97-107.

5. Walker LE, Shapiro DL: Parental alienation disorder: why label children with a mental diagnosis? Journal of child custody 2010, 7:266-286.

6. Hoult J: The Evidentiary Admissibility of Parental Alienation Syndrome: Science, Law, and Policy. Children's Legal Rights Journal 2006, 26:1-6.

7. Pignotti MS: La PAS ed il Codice di Deontologia Medica. Decidere in Medicina 2013, 4:12-15.

8. The role of the pediatrician in recognizing and intervening on behalf of abused women. American Academy of Pediatrics Committee on Child Abuse and Neglect. Pediatrics 1998, 101:1091-92.

doi:10.1186/1824-7288-40-S1-A34

Cite this article as: Pignotti: Parental alienation diagnosis. A modern and effective subtype of domestic violence, endemic in Italian courts. Italian Journal of Pediatrics 2014 40(Suppl 1):A34. 